\section{"Syndrome of Contractures and Deformities" according Prof. Hans Mau. Symptoms, diagnosis, treatment: Recommendations for parents}

\author{
Tomasz Karski* and Jacek Karski \\ 1Professor, MD, Vincent Pol University, Lublin, Poland \\ ${ }^{2} \mathrm{MD}$, Pediatric Orthopedics and Rehabilitation Department of Medical University in Lublin, Poland
}

\section{Abstract}

In development of movement apparatus in small children, youth and - if not cured - in adults play the role two factors. First is connected with small disorders in brain - and in Pediatrics Orthopedic Departments we see very often children with the symptoms of Minimal Brain Dysfunctions [MBD]. The second is connected with asymmetries in anatomy and in function of movement apparatus in "Syndrome of Contracture and Deformities" described by Professor Hans Mau (Tübingen, Germany). These second problems are the subject of this paper.

\section{More Information}

*Address for Correspondence: Tomasz Karski, Professor, MD, Vincent Pol University, Lublin, Poland, Tel: +48 604933 234;

Email: tmkarski@gmail.com;

t.karski@neostrada.pl

Submitted: 19 February 2020

Approved: 09 March 2020

Published: 10 March 2020

How to cite this article: Karski T, Karski J. "Syndrome of Contractures and Deformities" according Prof. Hans Mau. Symptoms, diagnosis, treatment: Recommendations for parents. J Adv Pediatr Child Health. 2020; 3: 021-023.

\section{DOI: 10.29328/journal.japch.1001012}

Copyright: (c) 2020 Karski T, et al. This is an open access article distributed under the Creative Commons Attribution License, which permits unrestricted use, distribution, and reproduction in any medium, provided the original work is properly cited.

Keywords: Deformity in newborn; Babies; Hips; Feet; Spine

\section{Check for updates}

OPEN ACCESS

\section{Introduction}

In paper we present the material from the years 1995 2019. Material contains 1555 children - newborns and babies as well young patients. Two elements play an important role in the development of the child's body and later its functions. The first one is connected with the asymmetries of the child's body in "Syndrome of Contractures and Deformities" [SofCD], and the other one with the Minimal Brain Dysfunctions [MBD] - nevertheless the second factor will be presented in another paper. The SofCD was precisely described in the 60 s by Prof. Hans Mau from Tübingen, Germany.

\section{General information about SofCD [1-8]}

In SofCD the anomalies of the child's body are caused by "improper, too small space in mother's uterus for the fetus". Exactly, the causes of SofCD are: higher weight of the fetus, greater length of the fetus's body and from the mother's side: small abdomen during pregnancy, lack of amniotic fluids (oligohydramion) and inconvenient - "androidal" or "platypeloidal" pelvic bone anatomy. First descriptions of the "Syndrome of Contractures" have been given by Prof. Hans Mau - as "Siebener [Kontrakturen] Syndrom" (Syndrome of Seven Contractures). In 2006 in Lublin we added to "the Syndrome of Contracture" an eighth deformity - bigger than normally "varus of shanks" and now, we call this syndrome, as the written above, "The Syndrome of Contractures and Deformities" (SofCD).

\section{Clinical symptoms of SofCD (Figures 1-3)}

In the paper we present the clinical symptoms of the Syndrome of Contracture and Deformities (SofCD):

1. dysplasia of the hips (mostly left),

2. wry neck,

If all these asymmetries and deformities in SofCD are not treated in the early childhood - they can significantly influence the "healthy status" of the youth and the adults.

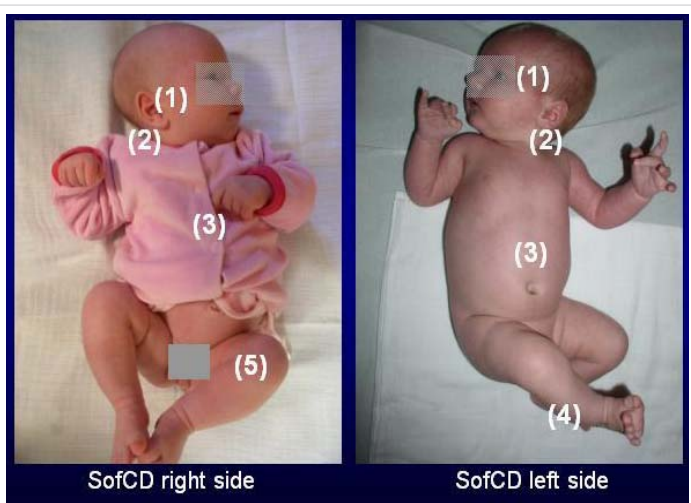

Figure 1: Symptoms of Syndrome of Contracture and Deformity [SofCD] according Prof. Hans Mau and Lublin observations: (1) plagiocephaly, (2) wry neck, (3) infantile scoliosis, (4) varus of the shanks, (5) limited abduction mostly left hip. 


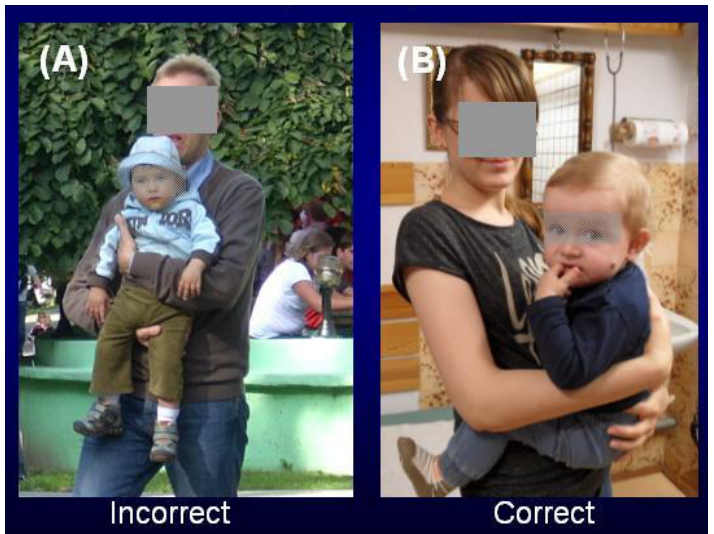

Figure 2: Nursing. (A) Incorrect carrying of the child - mistaken of recommendation in Poland and in other countries in Europe by some not proper educated doctors and physiotherapists. (B) Proper nursing of child - prophylaxis of dysplasia of the hips. Such carrying should be continued one year or longer.

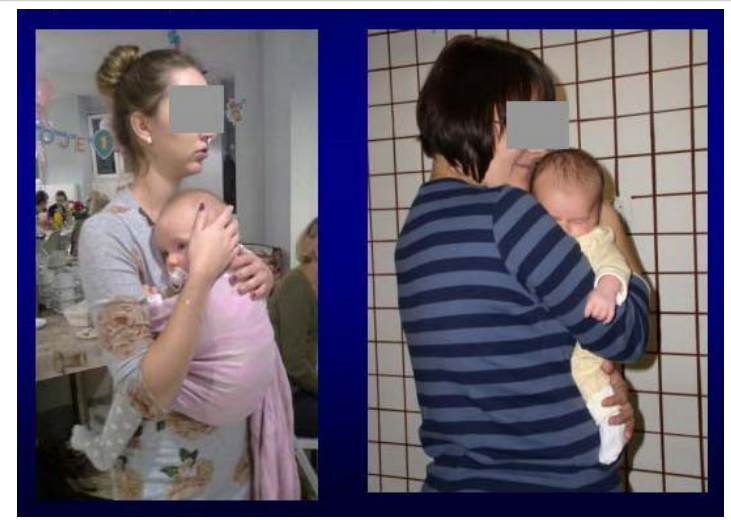

Figure 3: Nursing. On both Figures (A) and (B) - proper therapy of the wry neck left sided - in Latin - "torticollis sinister". The permanent position in rotation of the head to the left side is the best and only one proper method of therapy of the wry neck. Hips in abduction - prophylaxis of dysplasia.

\section{Primary description of the "Syndrome of Contractures" by Prof. Hans Mau}

In literature there were described:

1. Scull deformity (plagiocephaly),

2. Wry neck (torticollis muscularis),

3. Infantile scoliosis (scoliosis infantilis) - other than idiopathic scoliosis (T. Karski, J. Karski),

4. Limited abduction of the left hip. Untreated, can lead to the development of dysplasia. According to Prof. P. Klisic, it is the DDH (Developmental Dysplasia of the Hip DDH), what was mentioned earlier.

5. Contracture (shortening) of abductor muscles and soft tissues of the right hip according to T. Karski. By Prof. Hans Mau described as Haltungsschwäche ("weak posture") and is the cause of the oblique position of pelvis. Through function - "standing" and "gait" is the cause of the so-called idiopathic scoliosis (Adolescent Idiopathic Scoliosis [AIS]) - described in 1995 - 2007 by T. Karski.
6. Pelvic bone asymmetry, described by Prof. Mau according to our observations is caused by shortening (contracture) of adductors of the left hip and by shortening (contracture) of abductors of the right hip (explanation of T. Karski).

7. Foot deformities - such as: pes equino-varus, pes equinovalgus, pes calcaneo-valgus.

\section{Observations in Lublin}

Both authors (T. Karski, J. Karski) in 2006, as mentioned above, had to added to the "Syndrome of Contractures" in newborns and babies, as the eighth deformity, the excessive shank deformity (crura vara) which later can lead, under special conditions, to Blount disease [about this subject see article published in Germany and in USA - T. Karski, J. Karski]. Since 2006 we talk about the "Syndrome of Contractures and Deformities" (SofCD) what was described just in chapter earlier.

\section{Information about nursing of newborns and babies in points}

1. The carrying of the newborn and babies should be all time with full abduction and flexion of the hips-many hours every day and nights. It should be child's face directed to mother face-never "child's face to the street".

2. This position is important from the first or second day of child's life- and should be continued 12 month. It is the best methods for prophylaxis of dysplasia of the hips.

3. In some cases - we should use the abductions devices/ orthosis.

4. If the exist - wry neck/torticollis symptoms - the best therapy is "to turn the head of child to wry neck direction". Only rotation therapy - to stretch the shortened m. sterno - cleido - mastoideus is the proper therapy (see literature www.ortopedia.karski.lublin.pl point 17).

5. If the child start to stand and walk - we must remember that "standing on the right leg" is the cause in two form of the so-called idiopathic scoliosis in Lublin classification (see article sent to Redaction: Prof. Tomasz Karski, MD, $\mathrm{PhD}$ - So-called idiopathic scoliosis - disfigure deformity in children, pain problems in adults. Information about biomechanical etiology, classification and therapy).

6. The best prophylaxis rules again spine deformity are:

a. Standing 'at ease' on the left

b. Sitting relax - never straight up - important for spine

c. Sitting in "butterfly position" (term taken from karate) - important for hips, spine and knees.

7. As general recommendations - "mother feeding" of the child should be minimum one year. 
8. Four years long - never bind/tie the cap in the neck because can disturbed the blood circulation to the brain.

\section{Conclusion and practical information for pediatricians and other doctors}

All gynecologist and all pediatricians should be familiarized with the symptoms, diagnosis and methods of very early prophylaxis in cases of SofCD. In the paper we give simple information about proper nursing of the newborns and babies, we inform about methods of early physiotherapy. This simple methods of prophylaxis are very important for the proper development of hips, axis of legs and spine. The early program of prophylaxis is very important for proper development of the body for the whole life.

\section{Acknowledgement}

Many thanks for proofreading of the English text by Mr. David Poynton and Miss Honorata Menet.

\section{References}

1. Karski T, Kalakucki J, Karski J. Syndrome of contractures" (according to Mau) with the abduction contracture of the right hip as causative factor for development of the so-called idiopathic scoliosis. Stud Health Technol Inform. 2006; 123: 34-39.

PubMed: https://www.ncbi.nlm.nih.gov/pubmed/17108400

2. Karski T, Karski J. Syndrome of Contractures and Deformities" according to Prof. Hans Mau as Primary Cause of Hip, Neck, Shank and Spine Deformities in Babies, Youth and Adults. Am Res J Med Sur. $2015 ; 1$.

3. Karski T. Physiotherapy-Correct, or Incorrect, Based on 'Wrong Principles of Treatment'. Example for Spine, Hip, Knee, Shank and Feet, Crimson Publishers. 2017.

4. Karski T, Karski J, Karska K, Karska K, Menet H. Pediatric Prophylaxis Program of Motor System Deformations and Illnesses in Children. Problems of Spine, Hips, Knees and Feet. EC Paediatrics. 2018.

5. Karski T, Karski J, Karska K, Karska K, Menet H. Prophylactic Rules for Newborns, Babies, Children and Adults in problems of Hip, Knee, Shank, Feet and Spine. Online J CRIMSON PUBLISHERS. 2018.

6. Mau H. Zur Ätiopathogenese von Skoliose, Hüftdysplasie und Schiefhals im Säuglinsalter. Zeitschrift f. 294 Orthop. 1979; 5: 601-605.

7. Mau H. Die Atiopatogenese der Skoliose, Bücherei des Orthopäden, Band 33, Enke Verlag Stuttgart. 1982; 1.

8. www.ortopedia.karski.lublin.pl 